\title{
VIENNA, AN INTERCULTURAL AND COMMUNITY CULTURE CITY?
}

\author{
DOI: http://dx.doi.org/10.18509/GBP.2020.37
}

UDC: $316.334 .56: 303.8(436.1)$

\section{Walter Rohn}

Institute for Urban and Regional Research, Austrian Academy of Sciences, Vienna, Austria

\begin{abstract}
Due to the growing diversity of the population of major European cities, understanding between people or between different strata of the population does not get easier. Intercultural facilities and locations for community culture are in a position to help bridging the gap. The paper depicts and analyses Vienna's intercultural and community culture scene including its most important institutions, locations, places, associations, festivals, and actors.

Data presented in this contribution stem from a specific research project currently carried out by the author at the Institute for Urban and Regional Research of the Austrian Academy of Sciences in Vienna. The project focuses on the investigation of the possible positive effects of intercultural and community culture activities on intercultural dialogue, participation, inclusion, mutual understanding of different people, a stimulating and peaceful cohabitation, the amelioration of cultural and other infrastructures, as well as to a reduction of social and spatial imbalances and to a positive development of peripheral areas. For this purpose, the author applies the research methods of document analysis, field research, participant observation, and in-depth interviews with key actors in the given field.
\end{abstract}

Keywords: intercultural dialogue, cultural facilities, peaceful cohabitation, urban development, Vienna

\section{INTRODUCTION}

In European metropolises and cities, we are currently witnessing two important developments: on the one hand, urban areas are becoming increasingly diverse in terms of the origin of their population. Hence, understanding between people or between different strata of the population does not get easier. On the other hand, metropolises and cities are characterised by growing social imbalances (concerning wealth, salaries, housing, education, chances of individual development, etc.), which translate into spatial disparities in the residential areas of the better off and of disadvantaged people. According to the purchasing power of their inhabitants, the wider city centre and other living areas of privileged people dispose of a dense infrastructure, that is to say institutions of higher education and medical care, sophisticated shopping facilities, branch banks and cash machines as well as cultural institutions and facilities. Urban peripheries frequently house many disadvantaged people - among them many immigrants - and often lack infrastructure of the depicted kind.

\section{THEORETICAL ASPECTS}

Let us first explore some of the most important issues in the given field: Cultural urban development is a well-established strategy to develop cities and specific urban areas through cultural projects, festivals, and activities. This strategy has been described and 
analysed by scholars including Degen and Garcia [1], Ingram [2], McCarthy [3], Seo [4], Siebel [5], Ward [6], and Zukin [7].

The most comprehensive concept of cultural urban development, which also strongly emphasises the micro-level of specific urban areas, is Franco Bianchini's and Lia Ghilardi's Cultural Planning Approach (2004). Bianchini and Ghilardi depart from a broad definition of culture, so-called E-culture. They propose including all cultural resources of an area (neighbourhood, quarter, district, town, region etc.) and creating twoway relationships between cultural activities and other political fields such as architecture, urban planning, housing, economics, social affairs, education, and tourism [8].

The issue of arts, culture, and migration is discussed under several different headings: The first is cultural diversity, which refers to "the range of different cultures that are to be found in a given region or state, and to the manner in which these cultures coexist and the basis of that coexistence" [9].

UNESCO's Convention on the Protection and Promotion of the Diversity of Cultural Expressions (2005) defines the term in a more general way: "'Cultural diversity' refers to the manifold ways in which the cultures of groups and societies find expression. These expressions are passed on within and among groups and societies. Cultural diversity is made manifest not only through the varied ways in which the cultural heritage of humanity is expressed, augmented and transmitted through the variety of cultural expressions, but also through diverse modes of artistic creation, production, dissemination, distribution and enjoyment, whatever the means and technologies used" [10].

Intercultural dialogue points at establishing a "framework for relations" between states, organisations, or people. More specifically, intercultural dialogue aims at the creation of "common goods, shared knowledge and spaces for exchange" [11]. Intercultural dialogue may be seen as "a tool to reach out to individuals and members of specific communities, to encourage their participation in and increase their access to cultural life and to integrate their works and ideas into the community" [12].

Cultural diversity policies for the arts basically aim at giving special support to artists and associations from different cultural backgrounds to render possible a full participation of these creators in the respective scenes of arts and culture. At the supranational level intercultural dialogue may be fostered through bi- and multilateral cultural cooperation, the enhancement of the transnational mobility of artists, artist in residency programmes, as well as artist-led partnerships stretching out across national borders [13].

Intercultural cities are agglomerations with an ethnically diverse population which - by a variety of measures - try to turn diversity deficits into diversity advantages. Wood and Landry [14] identify five key factors for the making of an intercultural city: First, it needs a leader equipped with a certain cultural literacy who puts interculturalism on the agenda of the respective city and sets up a corresponding action plan. Second, creating an intercultural city requires looking at the city through an "intercultural lens". In the context of city management, which represents the third factor, decisive steps such as setting up a specific task force are being set. Fourth, the agenda of interculturalism requires an alternative citizenship based on belonging to a certain city. Fifth, residents of a city who can act as bridgers and mixers are of crucial importance.

In 2008, the Council of Europe launched its Intercultural Cities programme which is devoted to "capacity-building and policy-development". According to the programme, cities will develop "intercultural strategies for the management of diversity as a resource" 
[15] [16]. In 2020, 136 cities took part in the Intercultural Cities network, most of them in Europe [17].

In general, cultural facilities can be defined as venues such as theatres, cinemas, galleries, exhibition spaces, music venues, and multi-purpose locations [18]. In our context - with regard to European cities - we can distinguish between two types of cultural facilities: Intercultural facilities or centres basically serve the purposes of intercultural dialogue and cultural exchange. Bloomfield and Wood [19] describe intercultural facilities as venues to "rethink social, institutional, professional and status barriers as well as cultural differences, to create an expansive, participatory democracy and dynamic hybrid culture". In addition, Bloomfield and Wood [20] propose a typology of intercultural centres including (1) core-funded professional centres, (2) statutory services for inclusion across a territory, (3) regeneration-funded arts and resource centres, (4) municipally funded centres, (5) sectoral think tanks, and (6) autonomous, project-funded centres. Venues of community culture (or minority culture) conduce to the artistic and cultural selfrepresentation and to the empowerment of specific ethnic groups. The boundaries between intercultural and community culture facilities and activities are sometimes blurred.

The juxtaposition made here leads to the interesting question of how intercultural and community culture approaches differ from each other in their specific aims, strategies, and achievements. In the following the auhor will try to answer some of the questions.

\section{RESEARCH PROJECT}

The given issue is currently being investigated in the course of a research project on intercultural and community culture activities in Vienna, which is being carried out by the author at the Institute for Urban and Regional Research of the Austrian Academy of Sciences in Vienna. Depending on the availability of specific financial resources, the next steps will be setting up a case study on intercultural and community culture facilities in London and a comparison between developments in those two cities.

The basic research question investigated within the project reads as follows: In which ways can intercultural and community culture facilities and activities contribute to intercultural dialogue, participation, inclusion, mutual understanding among different people, a stimulating and peaceful cohabitation, the amelioration of cultural and other infrastructures, to a reduction of social and spatial imbalances, as well as to a positive development of peripheral areas?

Research work is done according to the research methods of

- Document analysis,

- Field research - Robert Ezra Parks' "nosing around" [21],

- Participant observation and finally

- In-depth interviews with managers of cultural facilities, artists, experts in the field of culture and political representatives.

\section{VIENNA'S INTERCULTURAL AND COMMUNITY CULTURE SCENE}

Since the beginning of this century, a small intercultural and community culture scene has begun to emerge in Vienna. The most important settings, activities, and actors of this culture scene will now be depicted. Under the heading of intercultural activities, we 
investigate institutions and locations, festivals, associations, and intercultural programmes at large cultural institutions. Community culture in principle comprises institutions and associations presenting a regular programme and locations with sporadic activities.

Before going into details, we wish to describe Vienna's spatial structure briefly: The districts 1 to 9, which are situated on the right bank of the Danube and inside the ringroad Gürtel, are considered as Vienna's inner districts. The districts 10 to 20 and the district 23 on the right side of the Danube and the districts 21 and 22 on the left side of the river are the outer districts of the Austrian capital.

First, let us discuss intercultural activities in Vienna. Under the heading of institutions and locations, the theatre laboratories Lalish ( $18^{\text {th }}$ district of Vienna) and DiverCITYLAB $\left(10^{\text {th }}\right)$ are to be mentioned. DiverCITYLAB serves as a school for young actors and is directed by Aslı Kışlal. Brunnenpassage $\left(16^{\text {th }}\right)$ is Vienna's flagship project in this field and presents various arts including theatre, literature, cinema, etc. Participatory formats such as different choirs and dance classes are of great importance here. Brunnenpassage has been initiated and is still supported by the social institution Caritas and is directed by Anne Wiederhold. Stand $129\left(10^{\text {th }}\right)$ is an offshoot of the Brunnenpassage and is led by Tilman Fromelt. Both facilities are neighbourhood projects. Furthermore, the cultural association and bookshop Afri-Eurotext $\left(2^{\text {nd }}\right)$ is to be mentioned.

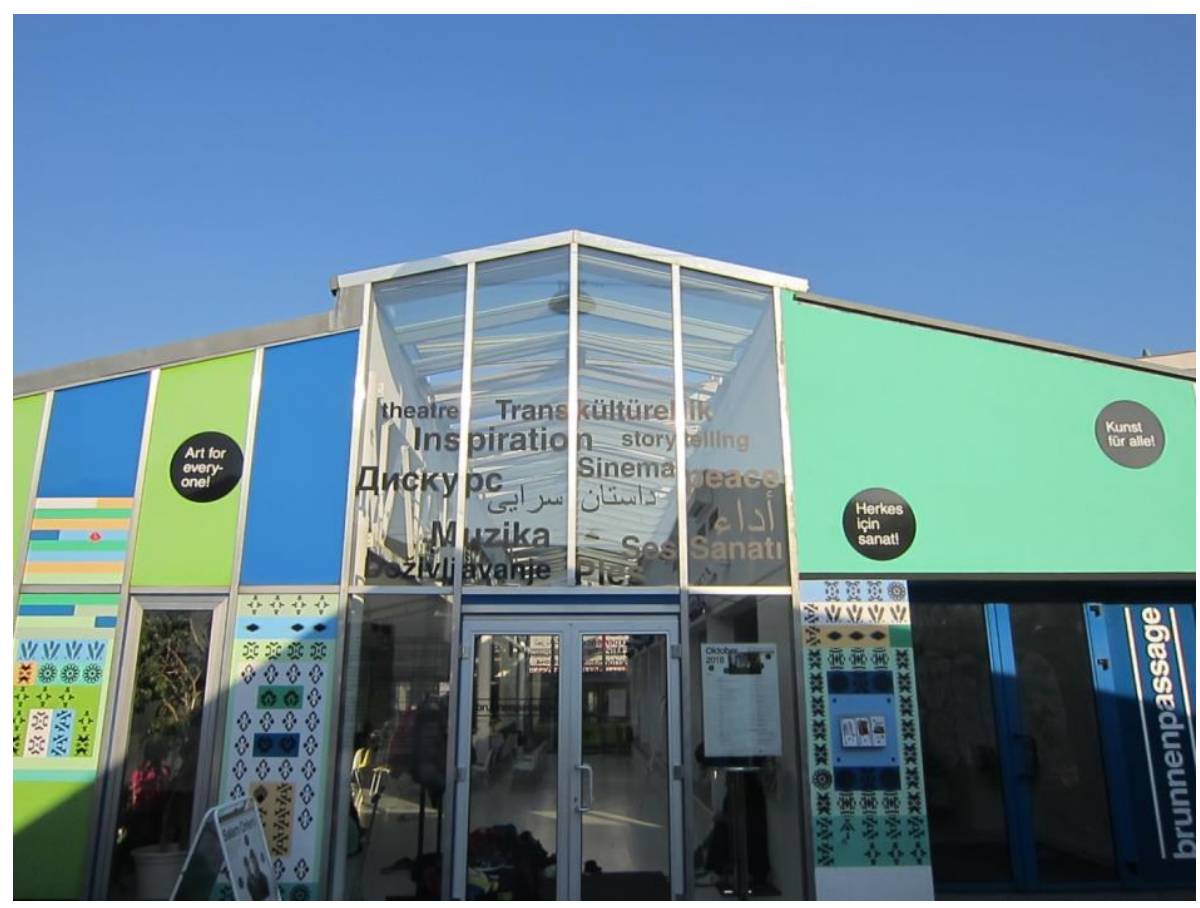

Figure 1. Brunnenpassage (2018 - all photos by Walter Rohn)

Kulturraum Neruda (4th), Centro Once (11th) and Café Derwisch (16th) offer music the first two facilities specialise in Latin American music, the latter offers different music styles. Hinterland Gallery (4th) and Philomena plus (2nd) present fine arts from the Middle East.

The intercultural festivals Wienwoche and Salam Orient offer various art forms. In Between at the Akzent theatre, the International Accordion Festival and the KlezMORE Festival Vienna present music programmes. With the exception of In Between, all festivals stage concerts, performances etc. at locations and places all over Vienna. 
Wiener Vorstadttheater and daskunst are associations in the field of theatre. Moving Cultures and BlueSimon specialise in music. Kültür gemma provides grants to migrants for training in cultural facilities and Diverse Geschichten supports the writing of screenplays.

Furthermore, large cultural institutions in the city centre such as the Burgtheater, Volkstheater, Quartier 21, etc. inter alia present intercultural programmes.

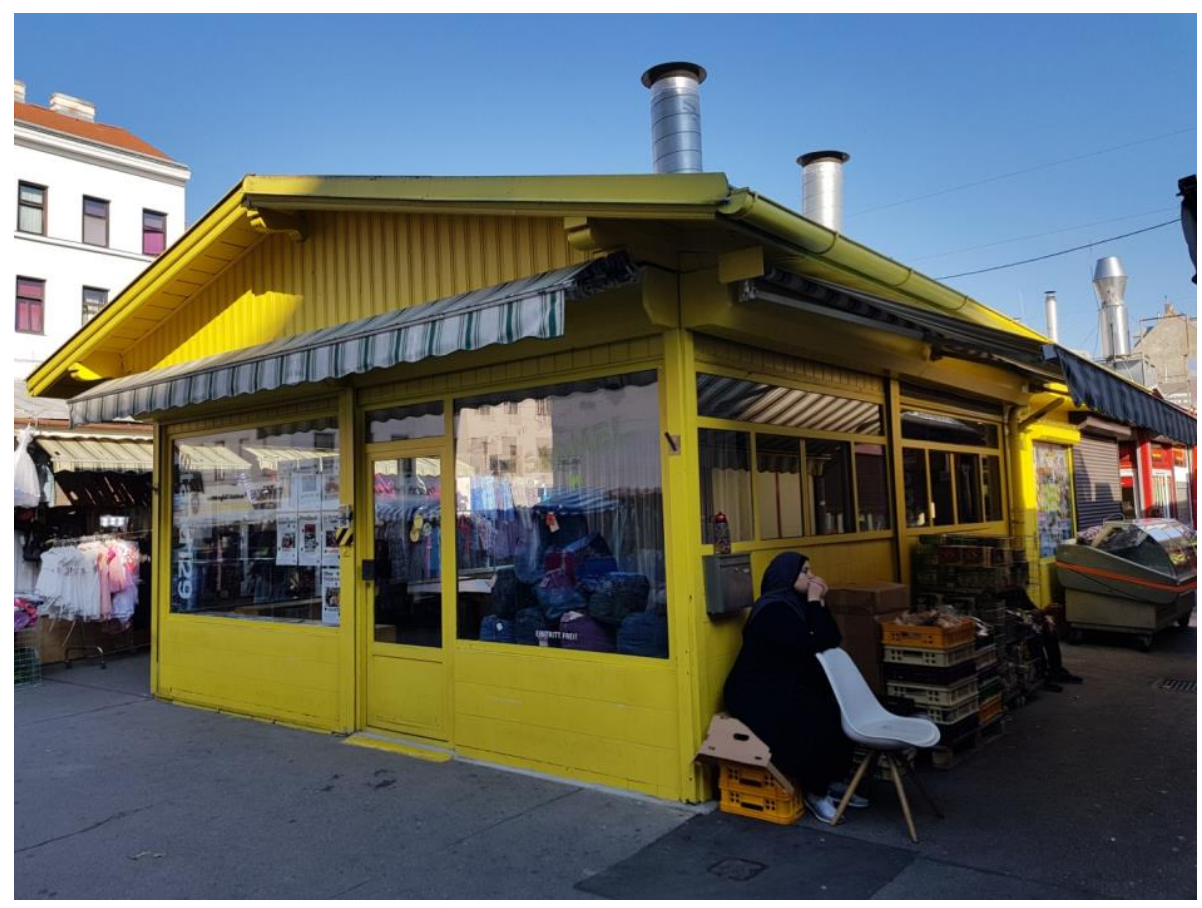

Figure 2. Stand 129 (2018)

Let us, second, turn to activities of community culture in Vienna. Under the heading institutions and associations, the following are to be mentioned: the Croatian Centre and the Burgenland-Croatian cultural association in Vienna (both 4th), as well as the Croatian cultural association Progress Austria-Vienna (15th) serve the Croatian community in Vienna. For people with a Serbian background, the Serbian Centre (7th), Serbian cultural centre Stevan Mokranjac (10th) and others act as anchors. The Yunus Emre Enstitüsü (9th) is the Turkish cultural institute. The cultural institutions listed above represent the countries where the greater part of the people who moved to Vienna come from. Furthermore, there are, e.g., the cultural institutes of the Czech Republic, Germany, Poland, Spain, Slovakia, and the United States of America (all 1st), France and Hungary (both 2nd), Bulgaria and Italy (both 3rd), Romania and Russia (both 4th), and Great Britain (7th). The Latin America Institute (9th) is currently struggling for its survival. The following locations sporadically present events of community culture: the Akzent theatre (4th) stages theatre productions from Croatia, Serbia, etc. Hallmann Dome, Arena34, and Kral Eventhalle (all 10th) are large halls where pop stars from the former Yugoslavia and Turkey perform. Restaurants and cafés at Ottakringer Straße (16th/17th) sporadically present concerts and other cultural events such as the film festival Balkanale. From time to time, multiplex cinemas such as the Hollywood Megaplex Gasometer (11th), Lugner City (15th), and Millennium City (20th) present films in Croatian, Serbian, and Turkish languages. 


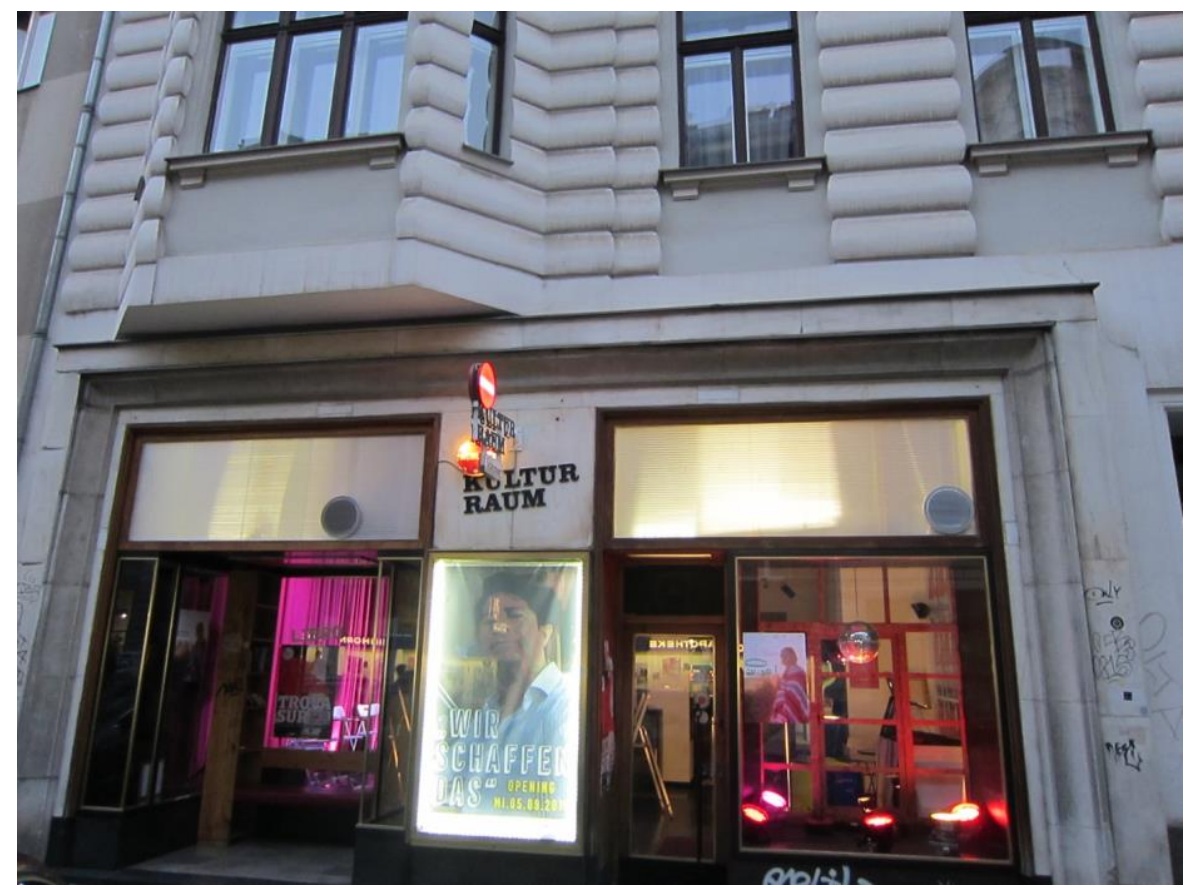

Figure 3. Kulturraum Neruda (2018)

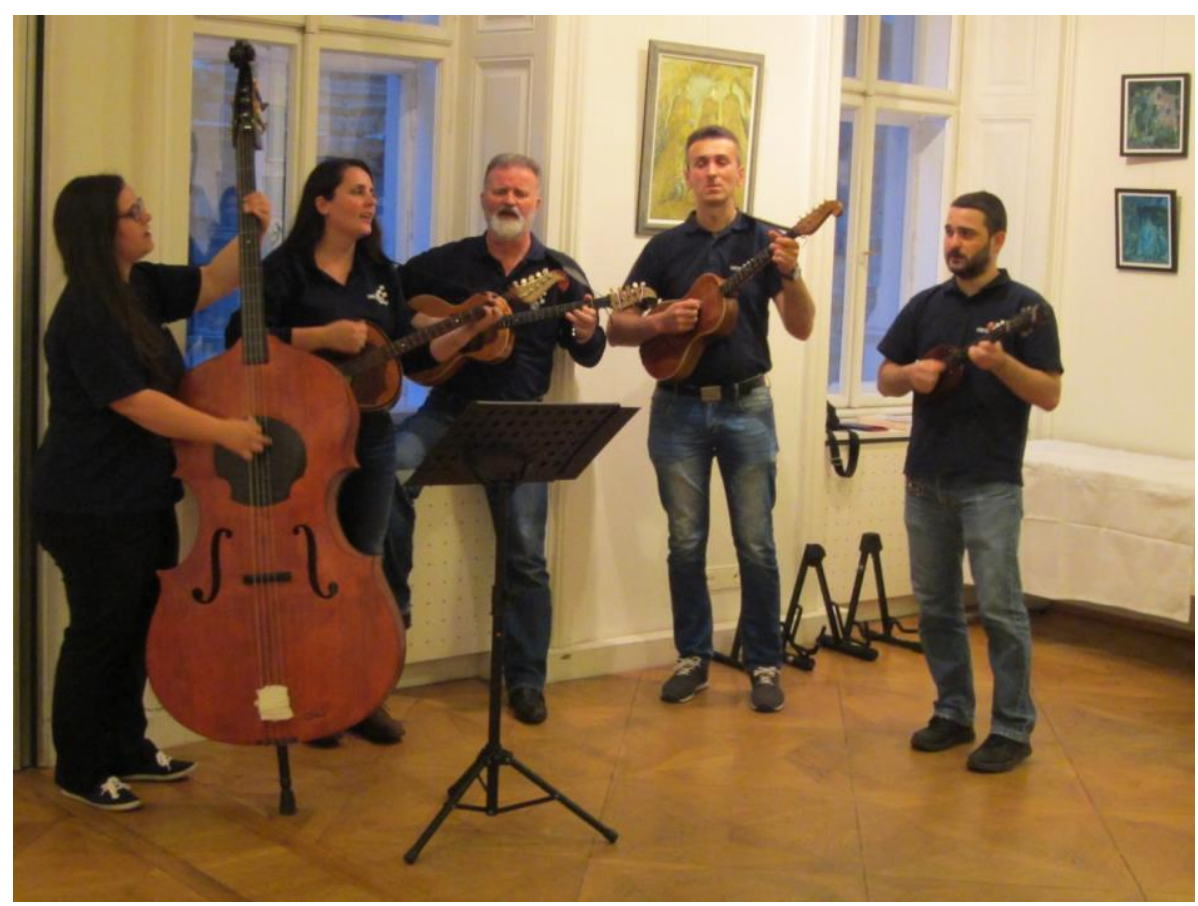

Figure 4. Concert at the Burgenland-Croatian cultural association in Vienna (2016)

Apart from the well-known places of community culture listed above, there are numerous small facilities serving the purposes of community culture in most of the outer districts of Vienna. Under the label MUSMIG, Ljubomir Bratic and others are attempting to establish a museum of migration, which does not exist yet in Vienna [22]. 


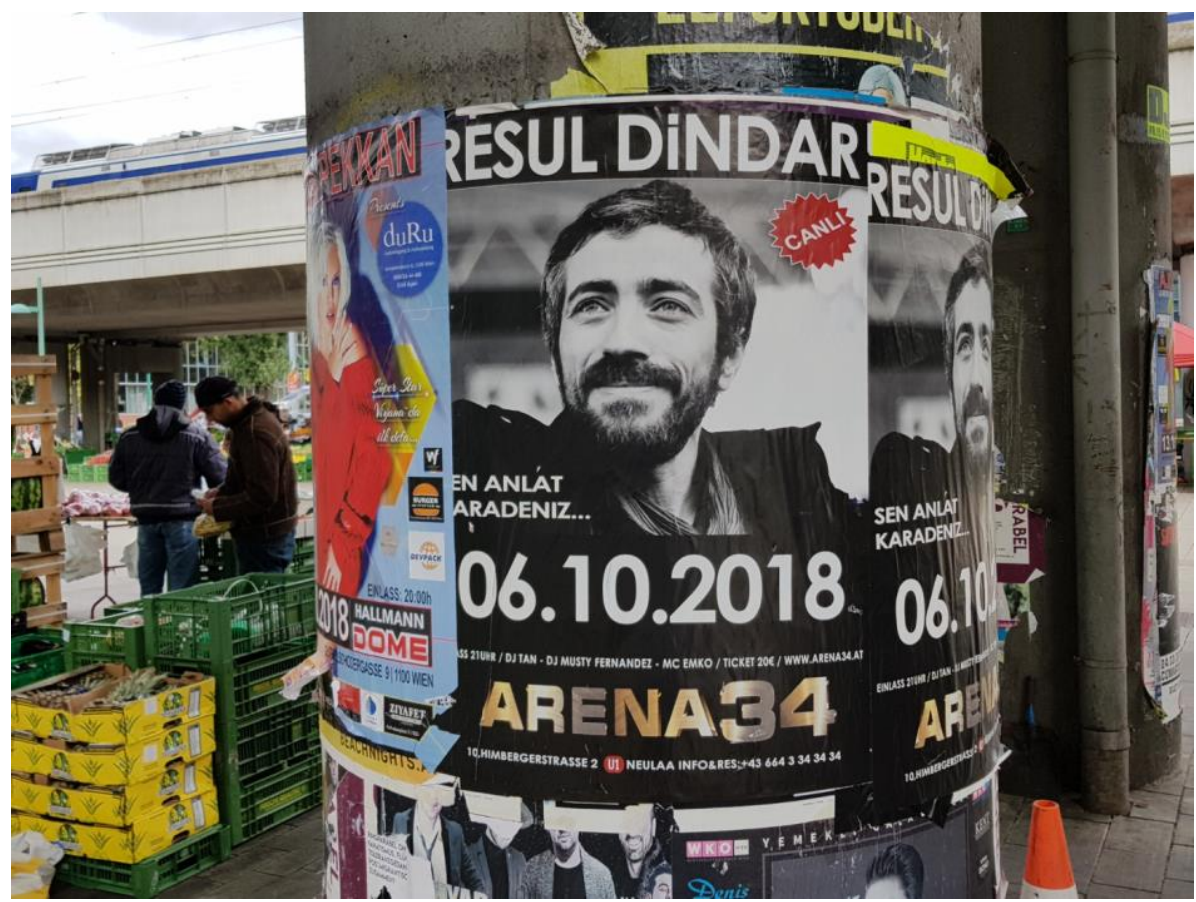

Figure 5. Announcement of a concert at Arena34 (2018)

\section{INTERPRETATION AND CONCLUSION}

Contrary to the general distribution of cultural institutions and facilities, which are heavily concentrated in the inner districts of Vienna, intercultural and community culture locations, projects, and activities are distributed all over the city.

Vienna offers a diverse mix of intercultural and community culture institutions, locations, halls, festivals, associations, and people who are active in this field, but this is still a very small scene.

Under the heading of intercultural activities, we count ten locations, five festivals and six associations. Including cultural institutes, there are a greater number of permanent locations of community culture and locations with a sporadic programme in Vienna than there are institutions dealing with intercultural issues. Only two locations, the Brunnenpassage and Stand 129, follow a neighbourhood policy.

Considering the differences between intercultural and community culture activities, we can furthermore say that in Vienna, community culture shows a slightly greater variety of art forms than intercultural ventures do.

To the knowledge of the author, Vienna has comparatively less and smaller projects than other cities such as, e.g., Berlin, London, and Paris. For the time being, we can only speculate on the reasons for that.

The Vienna municipality's cultural policy regarding intercultural and community culture activities, written down in the Government agreement between the Social Democratic and the Green Party of 2015 [23], is theoretically in good order, but there is a certain mismatch between the municipality's programme and its implementation.

A city may draw huge profits from the cultural diversity of its inhabitants and of their activities. As Wood and Landry [24] show, much depends on the will of the responsible persons in the city government. Vienna still has a long way ahead towards becoming a truly intercultural city with a strong community culture. It also still has to work towards gaining from the positive effects that the respective institutions, facilities, festivals, associations, etc. can bring about. These positive effects should ultimately improve 
mutual understanding, reduce social and spatial imbalances, and contribute to a positive development of peripheral areas. For the city of Vienna, a first step in this direction might be to participate in the Council of Europe's Intercultural Cities programme and to learn from other cities' experience.

\section{REFERENCES}

[1] Degen, Mónica and Marisol García. The Transformation of the "Barcelona Model": An Analysis of Culture, Urban Regeneration and Governance. International Journal of Urban and Regional Research vol. 36, 5, pp 1022-1038, 2012.

[2] Ingram, Mark. The Artist and the City in "Euro-Mediterranean" Marseille: Redefining State Cultural Policy in an Era of Transnational Governance. City \& Society vol. 21, 2, pp 268-292, 2009.

[3] McCarthy, John. Entertainment-led Regeneration: The Case of Detroit. Cities vol. 19, 2, pp 105-111, 2002.

[4] Seo, J-K, 2002. Re-urbanisation in Regenerated Areas of Manchester and Glasgow. Cities vol. 19, 2, pp 113-121, 2002.

[5] Siebel, Walter. Die Kultur der Stadt. Berlin, 2015.

[6] Ward, Stephen V. „Cities are Fun!“: Inventing and Spreading the Baltimore Model of Cultural Urbanism. Monclús, Javier and Manuel Guàrdia (Eds.). Culture, Urbanism and Planning. Aldershot, pp 271-285, 2006.

[7] Zukin, Sharon. Städte und die Ökonomie der Symbole. Göschel, Albrecht and Volker Kirchberg (Eds.). Kultur in der Stadt. Stadtsoziologische Analysen zur Kultur. Opladen, pp 2740, 1998.

[8] Bianchini, Franco and Lia Ghilardi. The Culture of Neighbourhoods: A European Perspective. Bell, David and Mark Jayne (Eds.). City of Quarters: Urban Villages in the Contemporary City. Aldershot, pp 237-248, here p 245, 2004.

[9] Jewesbury, Daniel, Jagtar Singh and Sarah Tuck. Cultural Diversity and the Arts Research Project: Towards the Development of an Arts Council Policy and Action Plan. Final Report. Arts Council. Dublin, p 30, 2009.

[10] UNESCO (Ed.). Convention on the Protection and Promotion of the Diversity of Cultural Expressions, p 13, 2018. http://en.unesco.org/creativity/sites/creativity/files/passeportconvention2005-web2.pdf (All internet sources accessed at 7 February 2020).

[11] European Union (Ed.). Report on the Role of Public Arts and Cultural Institutions in the Promotion of Cultural Diversity and Intercultural Dialogue. European Agenda for Culture. Work Plan for Culture 2011-2014. Brussels, p 10, 2014.

[12] IFACCA (Ed.). Achieving Intercultural Dialogue through the Arts and Culture? Concepts, policies, programmes, practices. Ifacca d'Art Report No. 39, p 16, 2009. http://media.ifacca.org/files/D\%27Art39Final.pdf.

[13] IFACCA (Ed.). Achieving Intercultural Dialogue through the Arts and Culture? Op. cit., pp $13-22$.

[14] Wood, Phil and Charles Landry. The Intercultural City: Planning for Diversity Advantage. London, pp 321-324, 2010.

[15] Council of Europe (Ed.). White Paper on Intercultural Dialogue. "Living Together As Equals in Dignity", $\quad \mathrm{p} \quad 2008$. https://search.coe.int/cm/Pages/result_details.aspx?ObjectID=09000016805d37c2. 
[16] Council of Europe (Ed.). Final Report - Evaluation of the Intercultural Cities Programme, 2015. https://rm.coe.int/1680307e66.

[17] Council of Europe (Ed.). Intercultural cities programme. Intercultural Cities: alphabetical list of cities, 2020. https://www.coe.int/en/web/interculturalcities/list-of-participating-cities.

[18] Rohn, Walter. Die neue Kultur am Rand der Städte: Wien und Paris. Vienna, p 11, 2013.

[19] Bloomfield, Jude and Phil Wood. Intercultural Spaces and Centres. What are they, what benefits do they bring, and how can they be encouraged as an essential part of the Intercultural Cities approach? , p 2, 2012. https://rm.coe.int/16803009c3.

[20] Bloomfield, Jude and Phil Wood. Intercultural Spaces and Centres. Op. cit., pp 2-3.

[21] Lindner, Rolf. Die Entdeckung der Stadtkultur. Soziologie aus der Erfahrung der Reportage. Frankfurt am Main, New York, p 9, 2007.

[22] All information on intercultural and community culture activities in Vienna is derived from the author's own search on the Internet.

[23] Stadt Wien (Ed.). Eine Stadt, zwei Millionen Chancen. Das rot-grüne Regierungsübereinkommen für ein soziales, weltoffenes und lebenswertes Wien (14.11.2015), pp 122-129, 2020. https://www.wien.gv.at/politik/strategien-konzepte/regierungsuebereinkommen2015/

[24] Wood, Phil and Charles Landry. The Intercultural City. Op. cit., pp 321-342. 